\title{
FEATURE
}

\section{Instructional Strategies for Digital Reference}

Methods to Facilitate Student Learning

\author{
Megan Oakleaf and \\ Amy VanScoy
}

Megan Oakleaf is Assistant Professor, School of Information Studies, Syracuse University, Syracuse, New York. Amy VanScoy is Associate Head of Research and Information Services, North Carolina State University Libraries, Raleigh, North Carolina. Submitted for review July 31, 2009; revised and accepted for publication December 8, 2009.
Reference \& User Services Quarterly, vol. 49 , no. 4 , pp. $380-390$

(c) 2010 American Library Association. All rights reserved.

Permission granted to reproduce for nonprofit, educational use.
In today's climate of accountability in higher education, most colleges and universities - and therefore academic librariesconsider student learning the cornerstone of their missions. Reference service is one area in which libraries can demonstrate their commitment to support student learning. Are librarians using reference service to teach students? Or are they letting teachable moments pass by? This study identifies eight instructional strategies librarians can apply in digital reference transactions and analyzes the presence of these strategies in digital reference transcripts. The results suggest that librarians use a few instructional strategies, but could learn and employ several more in their efforts to create information-literate students. The authors hope that increased training in the use of these eight instructional strategies will allow librarians to maximize their impact on student learning. Portions of this article were presented at the RUSA Reference Research Forum at the 2009 ALA Annual Conference.

n today's climate of accountability in higher education, most colleges and universities consider student learning the cornerstone of their institutional missions. Many academic library missions mirror this focus on student learning. Traditionally, the primary library service associated with the mission to increase student learning is information literacy instruction. However, the increased emphasis on accountability and assessment in higher education provides libraries with an opportunity to revisit other library services to examine their potential impact on teaching and learning. Reference service is one area in which libraries can reinvigorate their commitment to support student learning. Are librarians using reference service to teach students? Or are they letting teachable moments pass by? This study identifies eight instructional strategies librarians can apply in digital reference transactions and examines librarians' use of these strategies in one university's instant message (IM) reference service.

\section{LITERATURE REVIEW}

Many authors have underscored the instructional potential of reference service in both face-to-face and digital modes. For example, Moyo identifies the integration of instruction into reference service as a "growing need." Beck and Turner point out that in-person reference transactions occur at the user's time of need, when they are most open to learning. ${ }^{2}$ Elmborg describes instruction provided via reference service as "'authentic' in that the student has a specific project underway and has specific questions regarding how to 
proceed."3 And Avery emphasizes the importance of identifying teachable moments during reference transactions. ${ }^{4}$

A few authors have focused their studies on the potential instructional value of digital reference services. Although some studies acknowledge perceived barriers to instruction in the digital reference environment, many researchers believe that librarians should "take on the role of teacher" in digital reference. ${ }^{5}$ Some studies have attempted to estimate the amount of instruction that occurs during digital reference transactions. For example, Johnston found that 60 percent of the University of New Brunswick's digital reference interactions had an instructional component; Moyo found 82 percent at Penn State University; Desai and Graves registered 83 percent at Southern Illinois University Carbondale; and Ward reports 90 percent at the University of Illinois. ${ }^{6}$ Previous studies classify instruction in the digital reference environment in three main ways: (1) user requests for instruction, (2) the general nature of questions users ask, or (3) the specific information literacy content addressed by librarians (i.e. suggestions for database selections and keyword terms or the Association of College and Research Libraries' Information Literacy Competency Standards for Higher Education). ${ }^{7}$ However, the existing literature does not identify specific instructional strategies librarians can employ to transform any reference transaction into an instructional episode, although Desai and Graves call for more research in this area. ${ }^{8}$ The current study seeks to fill this gap by developing, on the basis of educational theory, a set of instructional strategies that can be used to teach during digital reference transactions. In academic libraries, these strategies can increase the learning of the largest group of digital reference users-students.

\section{METHOD}

To maximize the impact of digital reference on student learning, librarians can employ a variety of instructional strategies grounded in educational theory. At the outset of this study, the researchers developed a list of instructional strategies on the basis of educational theories, including metacognition, active learning, and social constructivism, as well as working definitions of each strategy. ${ }^{9}$

\section{Educational Theories}

\section{Metacognition}

Metacognition is often defined as "thinking about thinking" or the ability to be intentional and reflective about one's thoughts. Expert thinkers and learners are metacognitively aware of their mental processes. When working to solve a problem, they remember methods that they've tried in the past. They actively refine their problem-solving strategies by combining what works best for them, what is empirically known, and what others have experienced. Research indicates that people who employ metacognitive behaviors can more easily describe the initial state of a problem they want to solve, the goals they need to achieve to solve the problem, the tools they have at their disposal, and any constraints or barriers barring the path to achieving the solution. ${ }^{10}$ Because metacognitive behavior is the hallmark of an expert learner and thinker, librarians should seek to develop metacognitive skills in their students and expect to encounter students with widely varying metacognitive abilities. By integrating instructional strategies into their digital reference service, librarians can reinforce skills students currently possess and model skills students still need to acquire.

\section{Constructivism and Active Learning}

Active learning is a central tenet of constructivist learning theory and widely accepted as a hallmark of effective instruction. When people actively participate in real-world activities and problem solving, learning occurs. ${ }^{11}$ Librarians can employ active learning techniques during digital reference transactions to engage users in effective information seeking behavior.

\section{Social Constructivism}

According to social constructivist theory, what people learn is socially developed through interactions with "expert" members of a specific community. By interacting with community members, novice learners are acculturated in the knowledge and skills of the group before joining a community of expert learners. ${ }^{12}$ According to Elmborg, librarians who adopt a social constructivist model of instruction can guide users to become members of a community of information-literate people. ${ }^{13}$ By adopting specific strategies, digital reference librarians can acclimatize users to the information community.

\section{Instructional Strategies}

The researchers in this study derived eight instructional strategies from the three educational theories described above (see figure 1). Initially, seven strategies were developed. The researchers used 


\section{FEATURE}

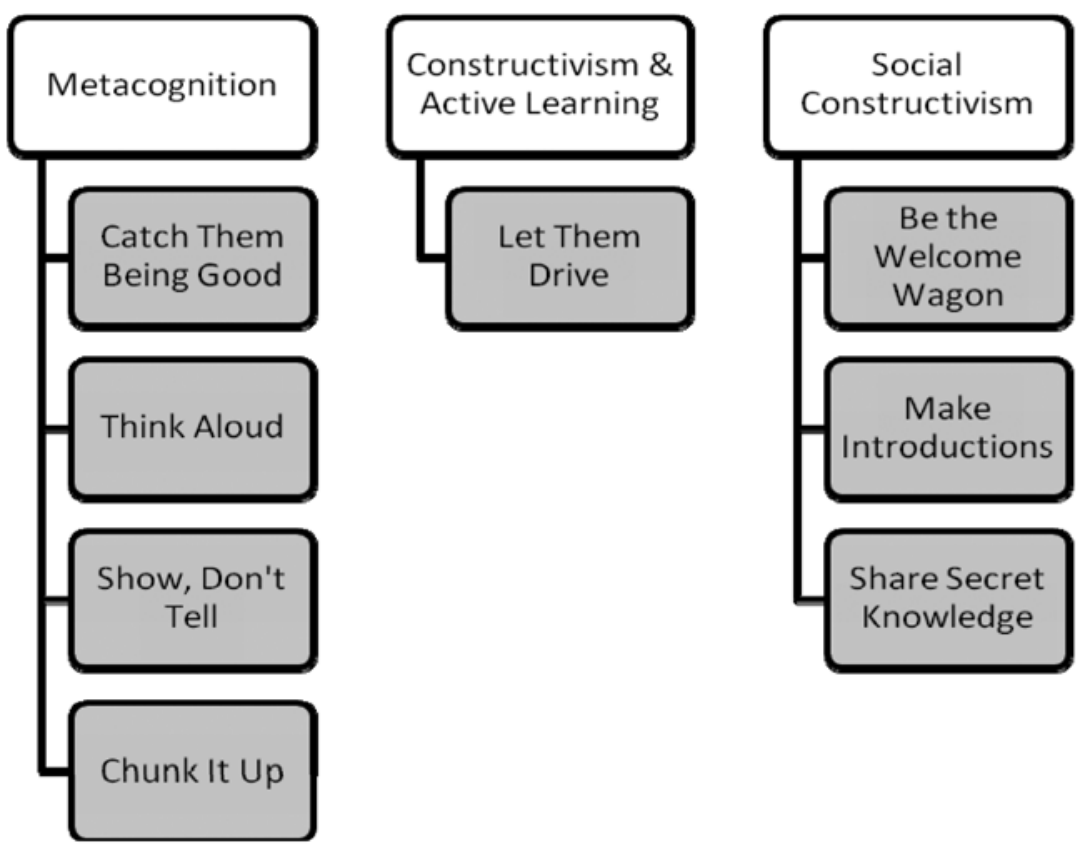

Figure 1. Educational Theories and Instructional Strategies

these strategies to analyze 150 digital reference transcripts as a pilot study. ${ }^{14}$ They independently coded each transcript using the seven instructional strategies, then peer-checked all of the transcripts for interrater reliability. During the pilot study, the researchers also examined the transcripts for the presence of unanticipated instructional strategies, but found none. However, they determined that one strategy could be subdivided into two separate strategies. Thus, after the pilot study, a final strategy was added to the list, making a total of eight instructional strategies. Finally, the researchers labeled the instructional strategies with "catchy" names to facilitate recall and use of the strategies by practitioners providing digital reference service.

\section{Catch Them Being Good}

In digital reference transactions, librarians can actively reinforce the positive information-seeking behaviors students demonstrate. Librarians who acknowledge and compliment student behaviors achieve three goals. First, they reveal to students that information-seeking is not random, but rather has a logical problem-solving process. As a result, students feel reassured that they are taking steps to solve their information need. They also become aware-or are reminded-that there are frameworks upon which information is structured. Students can apply new knowledge of information structures to solve their information needs. Second, librarians who catch students being good provide positive reinforcement of skills. Students feel that the information expert recognizes their hard work and that the information search they conducted before contacting a librarian was useful. Even students who have not engaged in preliminary information-seeking before contacting a librarian can be praised for their decision to seek expert assistance! Third, providing positive reinforcement offers librarians a way to cement productive behaviors in the students' minds and minimize their mistakes. As a result, when students look back on the information-seeking experience, they are more likely to recall the behaviors librarians wish them to add to their repertoire of information-seeking strategies.

\section{Think Aloud}

In the digital reference environment, librarians should make the effort to make their thoughts, as expert searchers, transparent to students through using think aloud techniques. Librarians who employ the think aloud strategy describe their cognitive process throughout the steps of the reference transaction. By making the effort to reveal internal thought processes, librarians achieve two important goals. First, thinking aloud allows students insight into the expert information-seeking process of librarians. Students can learn how librarians define an information need, or which tools librarians use and why they use them. They can also learn how librarians evaluate the sources they find. This strategy allows students a window into the minds 
of information professionals as they wrestle with information needs. Students can seek clarification, ask questions, and compare their own techniques with those the librarian suggests. Second, by making the information-seeking process transparent to students, librarians can share not only their successful strategies, but also their failures. In many cases, failed information-seeking strategies are even more instructive to students than successful ones. When a strategy fails, librarians are placed in situations students often encounter. However, librarians can reveal strategies for coping with failure by thinking aloud about why the strategy failed, what needs to be adjusted, and when to try an entirely new technique. Students share the journey and can benefit from witnessing the struggle. Finally, because students often save the transcripts of digital reference transactions, students can "replay" their conversation with a librarian whenever they encounter similar information needs. Consequently, librarians should not hesitate to put energy and enthusiasm into their digital reference transactions-their words may live on far longer than they think!

\section{Show, Don't Tell}

In digital reference transactions, reference librarians often have the opportunity both to describe the information-seeking process and to demonstrate it. While the think aloud technique highlights the importance of making expert information-seeking processes clear to novice library users, this strategy goes a step further. Whenever possible, librarians should show, not tell, students the steps of the information-seeking process. The options librarians have for showing students the information-seeking process vary depending on the technology used to provide digital reference service. This strategy may include "co-browsing" websites with students, "pushing" URLs or prepared materials (slides, audio files, or tutorials) to students, or encouraging students to open a browser window and follow along as the librarian completes a series of steps during the chat. Regardless of method, it is important to move beyond narrative to images and interaction. Librarians who use technology to engage students using visuals and real-time interactions achieve the important goal of addressing multiple learning styles. When librarians show, rather than tell, students how to proceed through the information-seeking process, they can appeal to multiple learning modalities. By addressing more than one learning style, students are more likely to internalize and retain the lessons they learn during the digital reference transaction.

\section{Chunk It Up}

In digital reference transactions, reference librarians should assist students with their immediate information needs and identify any additional steps students will face after the immediate need is met. Librarians may make students aware of future challenges and opportunities, offer advice, or-if students are ready to move to the next step-continue the reference transaction. During longer transactions, students may need time to work independently to complete a step. In such cases, librarians can "step out" of the conversation and reenter when students are ready to continue. When students complete their information-seeking process, librarians should encourage them to return to the digital reference service when a new need arises. Librarians who guide students to the next step of an information-seeking procedure reinforce the concept that information-seeking is a logical process and broaden students' perspective beyond the current stage of their search.

\section{Let Them Drive}

Because students learn more quickly and thoroughly when they are actively engaged in the learning process, it's important to "let them drive" during digital reference transactions. Librarians who employ this strategy can begin transactions by inviting students to describe or show what steps they've already taken in their information-seeking process. Throughout the reference transaction, librarians can encourage students to initiate actions while the librarian observes. The overriding principle for this strategy is to allow students to make decisions and take actions while librarians serve as guides who create connections, help students see patterns, ask relevant questions, and encourage reflection. Librarians who engage students in active learning achieve a number of goals. First, allowing students to drive provides librarians with the ability to view student information-seeking behaviors and identify areas to improve or reinforce. The observation of student behavior not only helps librarians assist individual students, it also may contribute to librarians' understanding of student information-seeking behavior over time. Second, the use of this technique ensures that students are actively participating in the reference transaction rather than passively waiting for their problems to be solved.

\section{Be the Welcome Wagon}

Digital reference transactions offer opportunities for librarians to support novice information seekers as they progress toward membership in the community of expert information seekers. To use 
this method successfully, librarians must focus on the goal: to prepare a new member to join their community. To achieve this goal, librarians should show enthusiasm for student requests for assistance. They should also respond to students in the context of a community of learners by fostering a climate of collaboration-explaining that others wrestle with the same issues and recognizing that students will pass on what they learn to others. Finally, librarians should acknowledge their students' current level of expertise and actively elicit feedback from students as the newest members of the information-literacy community.

\section{Make Introductions}

In digital reference transactions, librarians should direct students to other reference venues or specialized librarians when appropriate. As a rule, reference librarians should respond to students as completely as possible in the primary transaction. However, they may also wish to transfer the student seamlessly to another form of reference communication if the student's instructional needs can be better met by an alternative medium. Librarians may also make referrals to other library staff members who can augment the transaction with a specialized level of expertise. The referral might take the form of a second librarian entering the chat, a library staff member calling the student with additional information, or the provision of additional contact information to the student so that a consultation can be scheduled. The goal of

Table 1. Instructional Strategy Codes

\begin{tabular}{|c|c|}
\hline Codes & Description \\
\hline Catch Them Being Good & $\begin{array}{l}\text { - } \quad \text { Reinforce positive information-seeking behaviors } \\
\text { - } \quad \text { Acknowledge and compliment; recognize user's hard work thus far }\end{array}$ \\
\hline Think Aloud & $\begin{array}{l}\text { - Make librarian thoughts as expert researchers transparent to users } \\
\text { Describe cognitive process throughout the steps of the reference trans- } \\
\text { action } \\
\text { Give insight into the expert information-seeking process, a window } \\
\text { into the minds of librarians } \\
\text { - Share failures, as well as successes, and coping strategies }\end{array}$ \\
\hline Show, Don't Tell & $\begin{array}{l}\text { - } \quad \text { Demonstrate the information-seeking process } \\
\text { - } \quad \text { Push URLs, tutorials, etc. } \\
\text { - } \quad \text { Mompletes steps during chat } \\
\text { - Move beyond narration to images and interaction }\end{array}$ \\
\hline Chunk It Up & $\begin{array}{l}\text { - Identify additional steps the user will face after the immediate need is } \\
\text { met } \\
\text { Make users aware of or offer advice about future challenges and op- } \\
\text { portunities } \\
\text { - Step out of chat and reenter when users are ready to continue } \\
\text { Divide transaction into discrete, manageable chunks }\end{array}$ \\
\hline Let Users Drive & $\begin{array}{l}\text { - Invite users to describe or show what steps they've already taken } \\
\text { - } \quad \text { Encourage users to initiate actions while the librarian just observes } \\
\text { - }\end{array}$ \\
\hline Be the Welcome Wagon & $\begin{array}{l}\text { - Show enthusiasm for user requests for assistance } \\
\text { - Explain that other information-seekers wrestle with similar issues } \\
\text { Elicit feedback from users as newest members of information seeking } \\
\text { community } \\
\text { - Recognize user's expertise }\end{array}$ \\
\hline Make Introductions & $\begin{array}{l}\text { - } \quad \text { Redirect users to other reference venues if needs can be better met that } \\
\text { way } \\
\text { - } \quad \text { Refer to other librarians with specialized expertise }\end{array}$ \\
\hline Share Secret Knowledge & $\begin{array}{l}\text { - } \quad \text { Provide definitions for specialized community language } \\
\text { - Confide "tricks of the library trade" to users } \\
\text { - Explain the ethics, standards, or history of library services and policies } \\
\text { - Describe the scope of what librarians do }\end{array}$ \\
\hline
\end{tabular}


redirection in the digital reference environment is to facilitate the acclimatization of students into the community of information-literate people by providing instruction in the most efficient and effective manner. If the student's needs are specialized, it may be that a specialized librarian can offer additional information that will facilitate the acculturation process. Thus the goal of a referral to another library staff member is to ensure that the student is brought into the proper community of specialization.

\section{Share Secret Knowledge}

Digital reference transactions offer the librarians the opportunity to share the secret knowledge of the information-seeking community with students. To maximize this opportunity, librarians should provide definitions for specialized community language. By arming students with knowledge of library jargon, librarians prepare them to become equal members of the information community. Librarians should also acculturate students by confiding the "tricks of the library trade" and explain the ethics, standards, or history of library services, policies, and the role of librarians when relevant.

\section{Data Preparation}

After conducting the pilot examination of digital reference transactions and establishing definitions for eight instructional strategies, the researchers collected 1,474 instant message reference transactions. (These transactions were generated over the course of one academic year at a large southeastern research-extensive university that has offered digital reference service provided by reference librarians, support staff, and graduate assistants since 2001.) First, all personally identifying information (e.g., user and librarian names and e-mail addresses) was deleted from the transcripts. Next, each transcript was numbered. Then, the researchers worked independently to code transcripts for the presence of the eight instructional strategies (see table 1). To check for consistent coding, the researchers engaged in periodic peer checking; 80 percent of the transcripts were discussed by both researchers. Finally, the transcript numbers and codes were tabulated using a Microsoft Excel spreadsheet.

\section{RESULTS}

The results of the study demonstrated some use of instructional strategies in digital reference. In fact, 62 percent of the transcripts included at least one instructional strategy. A few transcripts include the use of multiple instructional strategies (see appendix A). However, a detailed breakdown of the instructional strategies reveals that many librarians do not take full advantage of the instructional opportunities that occur during digital reference transactions. For example, only 2 percent of digital reference transactions included the "Catch Them Being Good" instructional strategy (see appendix B). Slightly more transactions (6 percent) revealed the use of the "Think Aloud" strategy. A larger percentage (43 percent) of transactions included the use of a "Show, Don't Tell" strategy; however, most of this percentage is attributable to librarians pushing webpages or sending URLs to users. The "Show, Don't Tell" strategy of directing users to open browser windows and follow along with the librarian occurs in only 15 percent of the transactions. Three percent of the reference transactions include a "Chunk It Up" strategy, and the same percent of transactions exhibit a "Let Users Drive" instructional strategy. Librarians use a "Be the Welcome Wagon" strategy in 4 percent of reference transactions. The "Make Introductions" strategy is used in 18 percent of transactions librarians, 14 percent to other reference venues and 4 percent to experts. Finally, 8 percent of the transactions reveal a "Share Secret Knowledge" instructional strategy.

\section{DISCUSSION}

The results of this study demonstrate that, while librarians frequently use "Show, Don't Tell" strategies, many other instructional strategies are infrequently employed in digital reference transactions. Such results indicate that librarians may not be exploiting the full instructional potential of reference service; indeed, they may be letting many instructional opportunities pass by. To align reference service with the teaching and learning missions of libraries and their overarching institutions, librarians should recommit to the instructional role of reference and their professional responsibility to actively encourage student learning. One concrete way to support student learning is to learn instructional strategies and use them in the provision of digital reference service.

To increase the presence of instructional strategies in digital reference transactions, librarians can engage in a variety of professional development and training activities. For example, librarians can develop their skills in this area by obtaining outside training about digital reference instructional strategies in resources such as "Effective Instruction in the Virtual Reference Environment"15 or 
through consultant visits. Armed with the eight instructional strategies addressed in this article, digital reference librarians can analyze their own or a colleague's reference transactions for the presence of instructional strategies. Additionally, librarians can practice by rewriting past digital reference transcripts to include additional instructional strategies. Over time, reference staff can identify instructional strategies to adopt as standard practice for all librarians and align the use of instructional strategies with informationliteracy or general-education learning outcomes at their institutions.

\section{CONCLUSION}

Because this study represents a new approach to the study of instruction in digital reference, the results await confirmation by future researchers. Continuing research in this area should examine the presence of these instructional strategies at other institutions, evaluate the effectiveness of training librarians to use instructional strategies, investigate barriers to the use of these strategies, and explore the direct impact of librarian instructional strategies on student learning.

In the current climate of educational accountability, reference librarians should embrace the opportunity to align reference service with the teaching and learning missions of their libraries and overarching institutions. One way to integrate teaching into reference service is to employ a variety of instructional strategies throughout reference transactions. Are librarians using reference service to teach students, or are they overlooking instructional opportunities? This study indicates that librarians use some instructional strategies, but could learn and employ several more in their efforts to create information-literate students. In the future, increased training in the use of these eight instructional strategies may allow librarians to maximize their impact on student learning.

\section{References}

1. Lesley M. Moyo, "Virtual Reference Services and Instruction: An Assessment," Reference Librarian 95/96 (2006): 215.

2. Susan E. Beck and Nancy B. Turner, "On the Fly BI: Reaching and Teaching from the Reference Desk," Reference Librarian 72 (2001): 83-89.
3. James K. Elmborg, "Teaching at the Desk: Toward a Reference Pedagogy," portal: Libraries and the Academy 2, no. 3 (2002): 458

4. Susan Avery, "When Opportunity Knocks: Opening the Door through Teachable Moments," Reference Librarian 49, no. 2 (2008): 117.

5. Beth S. Woodard, "One-on-one Instruction: From the Reference Desk to Online Chat, Reference \& User Services Quarterly 44, no. 3 (2005): 203-209.

6. Laura Taddeo and Jill M. Hackenberg, "The Nuts, Bolts, and Teaching Opportunities of Real-Time Reference," College \& Undergraduate Libraries 13, no. 3 (2006): 82; Patricia E. Johnston, "Digital Reference as an Instructional Tool: Just in Time and Just Enough," Searcher 11, no. 3 (2003): 31-33; Moyo, "Virtual Reference Services and Instruction," 213-30; Christina M. Desai and Stephanie J. Graves, "Instruction via Instant Messaging Reference: What's Happening?” The Electronic Library 24, no. 2 (2006): 174-89; David Ward, "Measuring the Completeness of Reference Transactions in Online Chats: Results of an Unobtrusive Study," Reference \& User Services Quarterly 44, no. 1 (2004): 46-56.

7. Desai and Graves," Instruction via Instant Messaging Reference"; Moyo, "Virtual Reference Services and Instruction"; Johnston, "Digital Reference as an Instructional Tool"; Ward, "Measuring the Completeness of Reference Transactions in Online Chats"; Association of College and Research Libraries, "Information Literacy Competency Standards for Higher Education," www.ala.org/ala/mgrps/divs/acrl/standards/ informationliteracycompetency.cfm (accessed Feb. 20, 2010).

8. Christina M. Desai and Stephanie J. Graves, "Cyberspace or Face-to-Face: The Teachable Moment and Changing Reference Mediums," Reference \& User Services Quarterly 47, no. 3 (2008): 242-50, 252-55.

9. Amy VanScoy and Megan Oakleaf, "Effective Instruction in the Virtual Reference Environment," in Teaching with Technology: An Academic Librarian's Guide, ed. Joe Williams and Susan Goodwin (Oxford: Chandos, 2007): 65-86.

10. Janet E. Davidson and Robert J. Sternberg, "Smart Problem Solving: How Metacognition Helps," in Metacognition in Educational Theory and Practice, ed. Douglas J. Hacker, John Dunlosky, and Arthur C. Graesser (Mahway, N.J.: Lawrence Earlbaum, 1998): 47-68.

11. Mary Lamon, "Constructivist Approach," in Encyclopedia of Education, ed. James W. Guthrie (New York: Macmillan, 2003), 1463-66.

12. Ibid.

13. Elmborg, "Teaching at the Reference Desk," 455-64.

14. Megan Oakleaf and Amy VanScoy, "Using Educational Theory to Enhance Virtual Reference Instruction: A Study in Progress," (presentation, Association of Library and Information Science Annual Conference, Seattle, Jan. 15, 2007).

15. Vanscoy and Oakleaf, "Effective Instruction in the Virtual Reference Environment" 


\section{APPENDIX A. EXAMPLE OF TRANSCRIPT INCLUDING MULTIPLE INSTRUCTIONAL STRATEGIES}

(20:29:51) User: Hi, is may I ask a question from someone on here?

(20:31:53) User: me excuse my first sentence, I now see it did not make sense... I was just wondering if I am doing this right to talk to someone for help on finding an article?

(20:33:22) Librarian: Yes you are.

(20:33:22) User logged in.

(20:33:47) User: okay, great ... sorry for the way i first started out ... i was alittle confused

(20:33:56) Librarian: That's okay!

(20:34:07) User: I had a question about finding some journal articles

(20:34:42) Librarian: Okay. What is your topic?

(20:35:13) User: I am in a class at state "teaching math with technology" and have a project coming up dealing with choosing a big topic and then researching it using journal articles, so my topic is functions and graphs, but specifically dealing with algebra at the middle school level

(20:35:31) User: so i'm not exactly sure how one would go about finding articles for that!!!

(20:36:16) Librarian: That's a pretty specific topic!

(20:36:36) Librarian: Have you searched the ERIC database yet?

(20:37:22) User: well . . i tried, but i don't think i actually did ... i kept trying to get into this thing ... like EBCOS (or something like that ?) maybe EBHOST or something similar but i could never get to ERIC

(20:37:45) Librarian:

Ebsco is that platform that Eric is on.

(20:37:52) User: yes

(20:37:54) User: that was

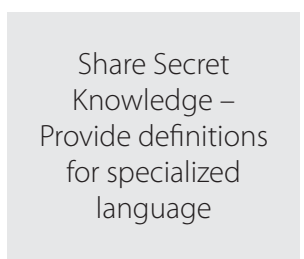

it

(20:38:01) Librarian: So you were searching Eric.

(20:38:13) Librarian: Let me see what I can find.

(20:38:18) User: but $i$ was on one thing and $i$ thought $i$ found an article $i$ wanted and then it was saying i had to pay like 30 dollars, so i don't htink it was ERIC

(20:39:41) Librarian: We do not have access to all items listed in ERIC.

(20:40:19) Librarian: ERIC is a database that indexes articles and documents by keywords.

(20:40:33) Librarian: It doesn't show exactly what we have in our collection.
(20:41:15) Librarian: Sometimes there are links that say "Full text from ERIC" in which the documents are available for free.

(20:41:25) User: this is going to sound kind of like a dumb question, but sometimes i look for just specifically journals, and then it comes up with all "articles" is that the same thing?

(20:41:59) Librarian: I am not sure what you mean.

(20:42:11) Librarian: Where are you searching for journals?

(20:42:25) User: I thought I was . . but I wasn't sure

(20:42:35) User: I will be able to figure it out though.

(20:42:48) User: that was just kind of a side note question

(20:42:59) Librarian: Is there any way that you can come to the library in the next day or two??

(20:43:11) User: yes, I was planning on trying to come tomorrow

(20:43:21) User: depending on how time goes

(20:43:55) Librarian: I really think that if you come to the reference desk and speak with one of the librarians in person-you will understand the total research process better.

(20:43:59) Librarian: Because-

(20:44:45) Librarian: it seems to me that you are having difficulty (like many students do) in understanding how to use the library catalog $\mathrm{v}$ using databases to locate articles.
Be the Welcome Wagon -Explain that other information seekers wrestle with similar issues
(20:45:35) Librarian: I will be glad to help you try to find some articles this evening, but I think it would really help to come to the library this week as well.

(20:47:15) User: well . . . i still have alot time to do this project, so i will just start by coming in tomorrow or sometime soon

(20:47:56) Librarian: Okay-but let me at least give you an initial search to do in ERIC— - b/c I did locate some articles that may be of use to you.

(20:48:33) User: ok, great!

(20:48:34) User: thanks 
(20:49:25) Librarian: Go to ERIC. You will see three search boxes. In the top box enter middle school in the second box enter algebra in the third box type graphs

(20:51:40) User: okay . . i am getting to ERIC now

(20:52:50) Librarian: Have you been able to enter the search terms yet??

(20:52:53) User: yes

(20:53:11) Librarian: Do any of the articles look like they would be of use to you?

(20:53:36) Librarian: I think I got a list of about 23 articles.

(20:54:04) User: yes, some of them do, but i don't know if this makes sense what i'm asking, (yes, i have 23 also!) but are all of these journal articles?

(20:54:44) Librarian: One thing that I did noticethe second article is in a journal called "Mathematics Teaching in the Middle School." I just checked our library catalog to see if we have that in our collection-we do.

(20:55:32) Librarian: So that may be a journal title that you could write down the title of and bring it to the library to have them show you an example of how to search the catalog for a particular journal.

(20:55:33) User: so, what does that mean . . . like you have the actual journal on hand at the library?

(20:56:44) User: also . . . is there any way for me to save this search, so tomorrow when i am working on this some more i can pull this exact list of articles i am viewing up on my computer screen, without typing in all the searches again?

(20:58:22) Librarian: Yes-we do have the actual journal in the library.

(20:58:47) User: ok, great . . . i will come and look through it hopefully close!

(20:58:56) User: (soon*)

(20:59:30) Librarian: But I would have them show you at the desk how to specifically search for articles in that particular journal using the database (instead of manual flipping through all of the journal issues).

(20:59:50) Librarian: Let me see-I think there is a way to email that search to yourself . . .

(21:00:37) User: it says "sign in to My EBSCOhost"

(21:00:40) Librarian: Hm.

(21:00:45) User: can you just create an account?

(21:00:49) Librarian: Yeah, it got the same as well.
(21:00:55) Librarian: I don't think that you can.

(21:01:21) Librarian: What i would do is copy and paste this IM transcript into a word document and save it.

(21:01:29) User: well . . . i should be able to create the same list tomorrow or within the next few weeks, by typing in the different searches like we did, right?

(21:01:38) Librarian: Exactly.

(21:01:44) User: so . . . i will be fine

(21:01:57) User: i think my main thing was what to type where in the search boxes

(21:02:08) User: getting that again shouldn't be a problem

(21:02:26) Librarian: I have no doubt that you will be. Do come by the library, though-so that we can show you how to retrieve some of the items you may not be able to instantly get to.

Chunk It Up Make patrons aware of or offer advice about coming challenges and opportunities

(21:02:44) User: and then

if $i$ wanted to focus more on functions, could i take out the last box where we put graphs and just put functions

(21:02:48) User: ?

(21:03:02) User: because i am kind of wanting to look at them together

(21:03:19) User: but i may find that these articles have some of them together already through us just putting graphs

(21:03:32) Librarian: Yes.

(21:03:34) User: since they do go together at this math level

(21:03:36) User: okay great!

(21:03:50) User: and these are all journal articles right?

(21:05:00) Librarian: That's the tough part with ERIC. Some of them are, some of them aren't. There are professional educational documents in ERIC that are not necessarily scholarly.

(21:05:35) Librarian: Again, since you have some time before the assignment is due-come by the library and ask them to explain it to you.

(21:06:03) User: ok ... i def. will, but just having this list and the actual articles tonight will help me to get somewhere! thanks soo much

(21:06:20) Librarian: You're quite welcome.

(21:06:27) Librarian: Have a good night. 


\section{APPENDIX B. PERCENT OF TRANSCRIPTS CONTAINING INSTRUCTIONAL STRATEGIES AND ILLUSTRATIVE EXAMPLES}

\begin{tabular}{|c|c|c|}
\hline $\begin{array}{l}\text { Instructional } \\
\text { Strategy }\end{array}$ & $\begin{array}{l}\text { Portion of } \\
\text { Transcripts }\end{array}$ & Example from Transcripts \\
\hline $\begin{array}{l}\text { Catch Them } \\
\text { Being Good }\end{array}$ & $2 \%$ & $\begin{array}{l}\text { User: I'm trying to write a page a day. } \\
\text { Librarian: So you have plenty of time to order the best sources in case we don't } \\
\text { have them here. } \\
\text { Librarian: Good strategy! } \\
\text { Librarian: Once you have done some planning, reading, and thinking it will go } \\
\text { a lot faster. } \\
\text { User: Yea... it seems like the hardest part is just gathering the sources. } \\
\text { Librarian: Alternating between research and thinking/writing tends to be a } \\
\text { good strategy. } \\
\text { User: Yea. } \\
\text { Librarian: And then you'll have more questions in your mind, so you can come } \\
\text { over and gather some more since you are giving yourself plenty of time. }\end{array}$ \\
\hline Think Aloud & $6 \%$ & $\begin{array}{l}\text { Librarian: What exactly do you mean by community impact? } \\
\text { User: Like what kind of people would live in an area ... would it affect the kind } \\
\text { of people that live in a community ... fancy people ... the like } \\
\text { Librarian: It would affect people with more money_-is that it? } \\
\text { User: Yeah ... I'm thinking that it would pull in people with higher incomes... } \\
\text { because the environment would be cleaner ... } \\
\text { Librarian: Hmm, looking through results in Academic Search, thinking of how } \\
\text { you'd find this sort of thing. One minute. } \\
\text { User: Thanks. } \\
\text { Librarian: It's so easy to find articles on bio fuels, but so hard to find what } \\
\text { you're looking for. The articles are all about the engineering aspects ... } \\
\text { User: Yeah. } \\
\text { Librarian: That's not to say there aren't articles, however. } \\
\text { User:True. } \\
\text { Librarian: I've been trying to find them doing variations like this ... } \\
\text { Librarian: (bio fuels or biofuels) and consumer* } \\
\text { Librarian: (bio fuels or biofuels) and community } \\
\text { User: Right. } \\
\text { Librarian: (bio fuels or biofuels) and social* } \\
\text { User: That produced one! } \\
\text { Librarian: Maybe look at books? See www.library.edu/catalog/searchresult } \\
\text { Librarian: Maybe a book length treatment would get into the social impacts? } \\
\text { Not sure. } \\
\text { User: Thanks for finding that! }\end{array}$ \\
\hline Show, Don't Tell & $43 \%$ & $\begin{array}{l}\text { User: Is carbon dioxide a primary pollutant or a secondary pollutant? } \\
\text { Librarian: Hmmm ... Let me see what I can find out. } \\
\text { User: Thanks. } \\
\text { Librarian: My colleague just checked the Encyclopedia of Life Sciences } \\
\text { Librarian: Ok ... try this: www.library.edu/searchdatabases } \\
\text { Librarian: Click on the title of the encyclopedia } \\
\text { User: K } \\
\text { Librarian: Then search for "secondary pollutant" and click the first entry. } \\
\text { User: K } \\
\text { Librarian: You'll need to search using the "Search this Title" box on the right. } \\
\text { Librarian: The first entry is called "Ecophysiological Responses of Plants to Air } \\
\text { Pollution" } \\
\text { User: I'm checking it out. } \\
\text { Librarian: There's a table in that entry that lists CO2 as a "primary" pollutant. } \\
\text { User: Thank you very much! }\end{array}$ \\
\hline
\end{tabular}




\section{FEATURE}

\begin{tabular}{|c|c|c|}
\hline $\begin{array}{l}\text { Instructional } \\
\text { Strategy }\end{array}$ & $\begin{array}{l}\text { Portion of } \\
\text { Transcripts }\end{array}$ & Example from Transcripts \\
\hline Chunk It Up & $3 \%$ & $\begin{array}{l}\text { Librarian: There are several ways to find lit criticism. } \\
\text { Librarian: One way is to search the library catalog by keyword using the novel's } \\
\text { title \& the word "criticism"... } \\
\text { Librarian: So for example ... Moby Dick and criticism ... . although you'll find } \\
\text { tons for Moby Dick! } \\
\text { Librarian: You find whole books, but also book chapters (if you're looking for } \\
\text { something shorter than a book). } \\
\text { Librarian: Another way to find criticism about novels is to look for articles in a } \\
\text { database called MLA. } \\
\text { User: I think I'm looking for scholarly articles. } \\
\text { Librarian: OK, then MLA is the way to go... }\end{array}$ \\
\hline Let Users Drive & $3 \%$ & $\begin{array}{l}\text { Librarian: What do you think of the results from that search? } \\
\text { Librarian: It's hard for me to tell if any of those articles look relevant because I } \\
\text { don't remember what The Wasteland was about. } \\
\text { Librarian: To find out more info about the articles or books, click on the title. } \\
\text { User: OK, great, I'm searching now... } \\
\text { User: Some of the articles look good! }\end{array}$ \\
\hline $\begin{array}{l}\text { Be the Welcome } \\
\text { Wagon }\end{array}$ & $4 \%$ & $\begin{array}{l}\text { User: How do I find journal articles? Just like a book? } \\
\text { Librarian: You don't find journal articles like books ... } \\
\text { User: Every time I use the catalog thing, I just get confused. } \\
\text { Librarian: You need to use a special kind of search tool called an article } \\
\text { database to discover which articles exist on your topic ... } \\
\text { User: I've done that, but then it just confuses me. } \\
\text { Librarian: It's not uncommon for people to look for articles on a topic in the } \\
\text { catalog, but it doesn't include the information about the journal articles ... only } \\
\text { whether we have a particular journal in our collection ... } \\
\text { Librarian: I'm not surprised that you've been confused with finding journal } \\
\text { articles. It's not something you do every day. } \\
\text { User: Yes. } \\
\text { Librarian: Do you need to find journal articles now? } \\
\text { User: Yes. } \\
\text { Librarian: I'm happy to help you through IM! } \\
\text { User: Thanks for your help! }\end{array}$ \\
\hline $\begin{array}{l}\text { Make } \\
\text { Introductions }\end{array}$ & $18 \%$ & $\begin{array}{l}\text { Librarian: Also, I would really recommend that you meet with our business } \\
\text { librarian to see if she can help you find the kind of info you need in the business } \\
\text { literature. } \\
\text { User: Oh, OK! What are her hours? } \\
\text { Librarian: Her name is SuzyQ. } \\
\text { Librarian: www.library.edu/staff/suzyq/ } \\
\text { Librarian: She'll be a huge help, I bet. }\end{array}$ \\
\hline $\begin{array}{l}\text { Share Secret } \\
\text { Knowledge }\end{array}$ & $8 \%$ & $\begin{array}{l}\text { Librarian: So you know that article databases like JSTOR are search tools that } \\
\text { you can't find through Google ... } \\
\text { Librarian: They cost a lot of money and so that's why you have to go through } \\
\text { the library to get to them. } \\
\text { Librarian: The one we're going to use first is called MLA International } \\
\text { Bibliography... } \\
\text { User: OK } \\
\text { Librarian: It's got a crazy name and it sounds like what you'd use to make } \\
\text { your References list in your paper, but it's actually a big container (kind of like a } \\
\text { search engine) with information about articles published in literature and film. } \\
\text { Librarian: You can get to it like this... }\end{array}$ \\
\hline
\end{tabular}

